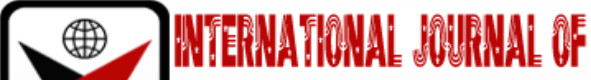

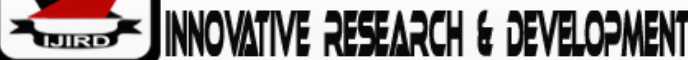

ISSN 2278-0211 (Online)

\section{Strategies Used by Heads of Schools in Enhancing Discipline in Secondary Schools in Siha District}

\author{
Gere Tumaini Msiba \\ Master's Candidate, Department of Education, Mwenge Catholic University, Tanzania \\ Victorine Salema \\ Lecturer, Department of Education, Mwenge Catholic University, Tanzania \\ Catherine Muteti \\ Lecturer, Department of Education, Mwenge Catholic University, Tanzania
}

\begin{abstract}
:
The study investigated the strategies used by the heads of schools in enhancing discipline in public secondary schools in Siha District, Tanzania. The study was guided by two research questions. This study adopted a mixed method approach under which a concurrent embedded design was be used. The sample for this study consisted of 4 heads of schools, 16 teachers, 240 students and 8 parents making a total number of 268 respondents. Data necessary to answer the research questions of this study was collected using questionnaires and interview guides. The study found that heads of school use punishment strategies to manage indiscipline cases in secondary schools. The study also found that sweeping, grass cutting, flogging, kneeling down, suspension and extra class work was used by heads of schools to manage students discipline problem. The study also found that heads of schools involve parents as strategies to manage students' indiscipline cases. The study concluded that heads of schools have to use punishment to manage indiscipline cases to students. punishment as school management tool has however resulted to some violent incidents of students' unrest in some secondary schools. The study also concluded that heads of schools have to involve parents in their children indiscipline cases. The study was recommended that Ministry of Education should provide policy guidelines on the use of guidance and counselling for the management of discipline in secondary schools. Increased efforts should also be made by the Ministry of Education, Department of Directorate of Quality Assurance and Standards to regularly supervise and monitor the schools which were not adhering to the ban on corporal punishment and were violating the child rights.
\end{abstract}

Keyword: Discipline, discipline management, punishment, guidance and counselling, public secondary school, academic performance

\section{Introduction}

School discipline is among the major concerns voiced by the public about school and the school systems in countries worldwide (Bussienei, 2012). These concerns come up when students riot, bully others in colleges and create violence in classrooms and playgrounds around their school compass. Behaviour problems are widespread in secondary schools that teachers are struggling to maintain order, and that school authorities are unable to guarantee the safety of students. According to Mwaura and Thinguri, (2015) schools are expected to be centres of formation of good behaviour and acceptable moral and social conducts among students. To ensure success in domestication of discipline, the heads of schools are a critical factor that will ensure that discipline is anchored in their schools.

Heads of schools as administrators in the institutions are the ones who plan, control, command, organise and coordinate all the activities that take place in the school and chairpersons of the disciplinary council in schoolsand provide final decisions to students whose conduct is not satisfactory. Heads of schools have records of students' indiscipline and are in better position to explain to other education stakeholders, especially parents on the conduct of their children. Thus, every school administrator requires a good measure of discipline in his school. Students' indiscipline is prompting a threat in all parts of the world in relation to children's affairs.

In Tanzania, students' discipline has been over time an issue of concern for educators, policy makers and public opinion in general, owing to the outbreak of aggressiveness among peers, violence within teachers and students' relationships and vandalism as well, leading to perpetual existence of the problem of drop out, deviant behaviors, lateness and poor academic performance among students (Kambuga, Patrick \&Mbalamula, 2018).Good discipline is considered to be one of the major attributes of effective schools and many failing secondary schools have been blamed for lack of discipline (Musa \& Martha, 2020).

The government of the United Republic of Tanzania (URT, 2019) officially reported students dropout rates in lower secondary education have varied more and tend to be somewhat higher whereby Form two has the highest number 
of dropouts. According to the report, the major reasons for dropout is truancy (62\%) followed pregnancy (37\%) and other misbehaviours (1\%). Majority of students in ordinary secondary have failed to continue with their studies due to their disciplinary actions committed at school such truancy and pregnancy. But, if provision of guidance and counselling to students and parents; advocacy to the community; legal enforcement; presence of school feeding programme; enhancement of extra-curricular activities including self-reliance activities; and sports and games in schools are effectively implemented to students can help to reduces indiscipline actions of the students (Machumbu and Killungwe, 2013).

Kambuga, Manyengo and Mbalamula, (2018)observed corporal punishment as a means of curbing disciplinary problems in Dodoma Municipal secondary schools in Tanzania. Corporal punishment has impacts in several ways some of which are worth mentioning fear, physical harm, psychological impact, dropout/absenteeism and hatred towards teachers who use corporal punishment in schools. However, in their findings showed that majority of the students proposed that corporal punishment should not be used, rather, teachers should use the nurturing strategies such as guidance and counselling and manual works should be used instead, to enforce discipline.

Provision of punishment, guidance and counselling and strong discipline committee were management strategies of students' indiscipline cases in public secondary schools. Ngalya (2017) argue that management of the issue of indiscipline has become a nightmare for school administrators and teachers in view of the increasing cases of this threat, its effect in effective management of schools as well as the ultimate effect on the society that is why there is need for each school to have a functioning disciplinary committee that sees to every case of acts of indiscipline of the students.

Koda and Kayombo, (2019) argue that the most and common disciplinary cases found in secondary schools in Moshi Municipality truancy, sexual misbehaviours, violence/fighting, using mobile phones in schools, alcoholism, the use of abusive of language, smoking, and pregnancy cases. Disciplinary problems can be the main hindrance to effective teaching and learning. It can also create violent and unsafe environment within a school community, resulting into lower achievement rates. Maintaining students' discipline is said to be the most difficult and unpleasant part of the teaching career due to globalization and the influence of social media. It is not surprising that discipline is categorically a major challenge facing school teachers in Tanzania (Yaghambe, 2013; Semali\&Vumilia, 2016; Kambuga, 2017). Traditionally, teachers in schools are not only tasked to teach but also at the same time are expected to manage students' behaviours to ensure that students engage in the broad activities related to teaching and learning.

Evidently, in schools due to overwhelming students' disciplinary cases, teachers spend many hours in correcting the behaviour and less in teaching.Lumanija\&Mkulu, (2020) in Baradi District observed that students are done different indiscipline cases which are very difficult for teachers to be aware of every student's behaviour in the school. Sometimes students they fight banning of dormitories, they steal school properties like chairs, books and others school accessories. According to John (2017) shows that there is disciplinary problem among students in Siha District Council. The disciplinary problems emanate from school environment and their homes. This can be attributed to students' exposure to things such as, mobile phones, televisions, alcoholism, cigarette smoking and theft as well as drug abuse, disobedience, truancy, banning of schools and dormitories, lack of punctuality and improper school uniforms. These disciplinary problems affect teaching and learning process in many of secondary schools in Siha District that need a way out to minimize the problems.

Moreover, John, (2017) observed negative responses of parents when they invited at schools where their children's studies. Little involvement of parents into their children's' disciplinary cases may be due to little awareness that student's good discipline is the key success for their academic performance. Indiscipline behaviours distract students' education progress, this reflects poor student's management in education institution. Heads of schools might employ several strategies suspensions, isolation, cleaning toilets and extra class work all these may reduce indiscipline actions that students commit. This makes the researcher to investigate the strategies used by the heads of schools in enhancing discipline in public secondary schools in Siha District Council.

\section{Statement of the Problem}

Students' indiscipline has become questionable by education administrators, teachers, parents and other education stakeholders. Parents, education administrators and other stakeholder are blaming heads of schools and teachers for students' indiscipline in secondary schools in Tanzania (Musa \& Martha, 2020). School indiscipline has owing to the outbreak of aggressiveness among peers, violence within teacher and student relationship and vandalism as well, leading to perpetual existence of the problem of drop out, deviant behaviours, lateness and poor academic performance among students.

Little attention has been paid on the strategies used by the heads of schools though heads of schools have been identified to play a crucial role in shaping students' discipline (Duda\&Susilo, 2018; Maingi et al., 2017). Majority of researchers have paid much attention on the challenges facing school management in enhancing students' discipline, leadership roles in effective implementation of school discipline policies and use of mobile phone on students' discipline. However, no studies have explained how the strategies of heads of schools can reduce indiscipline cases practiced by students in public secondary schools. In filling the gap, this study therefore investigated the strategies used by the heads of schools in enhancing discipline in public secondary schools in Siha, District.

\section{Research Questions}

This study was guided by the following research questions

- To what extent do heads of schools use punishment to manage indiscipline cases in public secondary schools in Siha District? 
- How do heads of schools involve parents in their children's indiscipline cases in public secondary schools in Siha District?

\section{Significance of the Study}

This study brings awareness to the public, Ministry of Education Science and Technology (MOEST)on the forms of punishments that used to enhance discipline among public secondary schools. These punishments recommend by the heads of schools to be used by teachers can enhance students' discipline. The findings of this study provide knowledge to the teachers on how to punish students in relation to their indiscipline actions. Moreover, the findings of this study bring awareness to the students about punishments used by the heads of schools by accepting those punishments when they misbehave. Additionally, the findings of this study bring awareness to the parents about their importance in involving into their children indiscipline cases at schools. Parents' involvement into their children's disciplinary cases can bring awareness to the parents about what are those indiscipline behaviours their children commit at school.

\section{Conceptual Framework}

Conceptual Framework is the analytical tool with several variations and contexts. It is used to make conceptual distinction and organize ideas. In this study the conceptual framework is as at Figure 1:

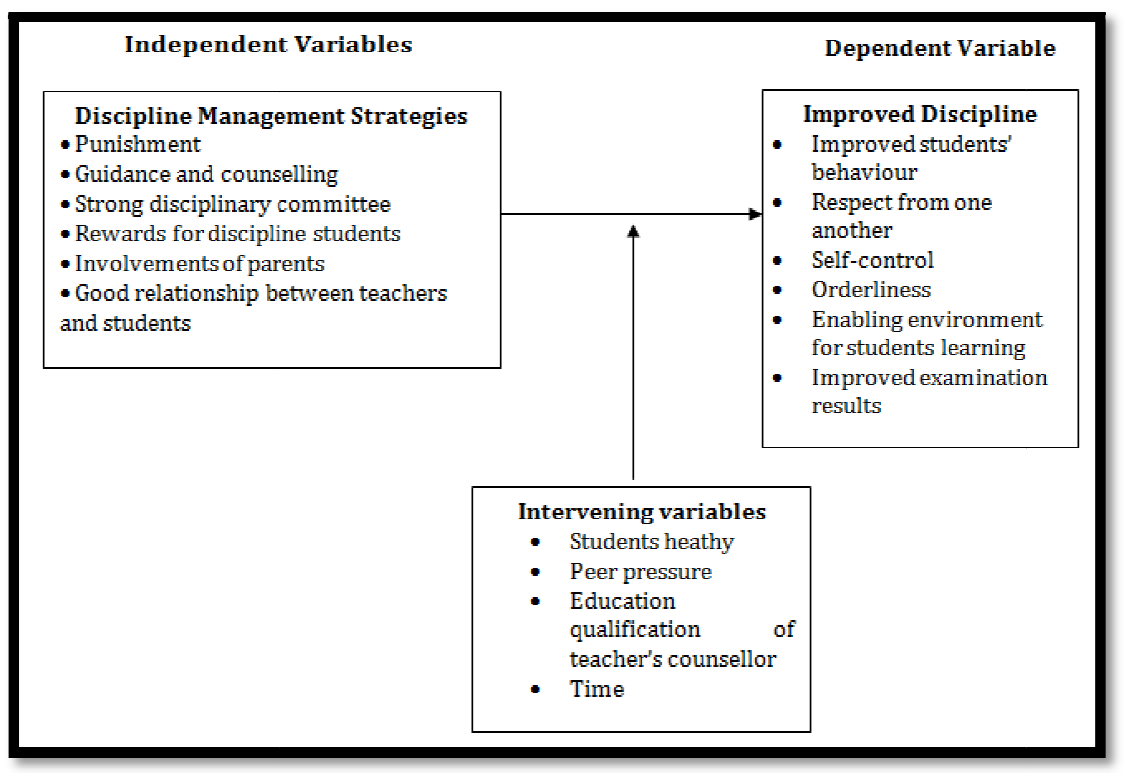

Figure 1: Conceptual Framework

Source: Researcher Own Construct, (2021)

Figure 1 show the relationship between independent variables (discipline management strategies) and dependent variables (improved discipline). Disciplinary management strategies are those strategies used by the heads of schools in enhancing discipline to students. Among those disciplinary management strategies are the use of punishments like extra works, manual works, canning with a stick, kneel down and toilets cleanness. In implementation of these punishments various factors may be intervening like student's health. The use of corporal punishment instils a level of respect in kids who struggle to interact with authority figures. It establishes a boundary between who is in charge, and what the rules happen to be. This process can then help to lay the groundwork for some children to understand the moments where they are asked to listen compared to the moments when they are allowed to explore personal choices with more freedom.

Heads of schools may use guidance and counselling services which encourages students to reflect back of their actions. Guidance plays a vital role in preventing educational, personal, social, mental emotional and other similar problems among secondary school students. It is through guidance and counselling that school administrators can manage discipline to students. The implementation of guidance and counselling might be affected by educational qualifications of teacher counsellors, time and resources. Guidance and counselling prepare students for academic, career, discipline and social challenges by relating educational agendas to their success in the future. Guidance and counselling are important for children, and schools have a huge role in bringing out the best in children. Good conduct is coveted, but sometimes young minds need guidance to polish their personality. Through counselling, children are given advice on how to manage and deal with emotional conflict and personal problems. Also, provision of guidance and counselling helps it helps to bridge the gap between students and the school administration, since they are able to guide their problems through a proper counselling channel in the office.

Strong disciplinary committee, reward giving to the discipline students, involvement of parents and good relationship between teachers and students. When indiscipline cases like drug abuse, absenteeism, fighting among students, word abuse and theft occur in the schools, teachers and heads of schools use different strategies to manage the case. Indiscipline cases can be managed with those strategies so as to control the discipline in secondary schools. 


\section{Review of Empirical Studies}

The scope of the literature review was to focus on the use corporal punishment to manage indiscipline cases, involve parents in their children indiscipline cases in public secondary schools in Siha District.

\section{Use of Punishment to Manage Indiscipline Cases in Secondary Schools}

Gershoff (2017)did a study on school corporal punishment in global perspective: prevalence, outcomes, and efforts at intervention in private schools in Texas, USA. The qualitative design was used whereby 45 teachers were sampled. Interview guide, focus group discussion and document analysis guide was used. The study found out that school corporal punishment (CP) is a fact of life for millions of children around the world, despite no evidence that it promotes learning and substantial evidence that it instead is linked with physical harm, mental and behavioural health problems, and impaired achievement. It is encouraging that 128 countries have banned corporal punishment, but there is still much work to be done to educate teachers about alternatives to corporal punishment so that they completely abandon its use in schools. The study done by Gershoff focus on the banning of CP in schools by mentioned its effects on students' health without provides alternatives punishments like sweeping, kneeling down and cleaning toilets that might improve students discipline and their academic performance. The study used case study design which offers intensive descriptions and analysis of a single unit system. The researcher could use convergent design which allowsto collect both qualitative and quantitative information from public secondary schools.

A quantitative study done by Nampoto (2018) on the aspects of corporal punishment on maintaining discipline in Tanzania secondary schools in Mtwara Mikindani Municipality. The sample size of the study includes 30 students, 4 members of school board, 2 discipline teachers and 1 head of school. Interviews and documentary review were used as research instruments for data collection. The study showed that corporal punishment in secondary schools in MtwaraMikindani Municipality, were used to maintain discipline. Moreover, heads of schools and members of school boards have the views that corporal punishment should continue to administer to students. The study concluded that school administration and teachers should administer corporal punishment side by side with other types of punishment so as to gradually introduce students to other types of punishment. The sample size for the respondents was little bit small to make the findings of the study to be generalized to the target population. This reflects inadequate empirical knowledge in heads of schools relations that needs to be established.

Kambuga, Manyengo and Mbalamula (2018), conducted a study on the corporal punishment as a strategic reprimand used by teachers to curb students' misbehaviours in secondary schools in Tanzanian. This study employed a quantitative approach using a descriptive survey design. The study sample size was 12 teachers and 45 students from secondary schools where by questionnaires were used as data collection procedure. The results revealed that majority of the teachers preferred Corporal punishment and continue using it as the only alternative punishment strategy. The study moreover found that the majority of students were of the view that corporal punishment should be eliminated due to its harm and cause for students dodging classes and absenteeism. The study design did not match with sample size of the study. The study sample size was too small compared to the research paradigms employed which allow involvement of large number of respondents. The current study used convergent design to collect qualitative and quantitative data by sampled 16 teachers, 240 students, 8 parents and 4 heads of schools.

Ishengoma(2014) did a study on the use of corporal punishment in maintaining discipline in Dodoma Municipality Secondary Schools. The study adopted both qualitative and quantitative approach. Only questionnaires were used as research instrument for data collection. The study findings showed that majority of teachers supported the use of CP in maintaining discipline to students but with moderation. They argued that, if CP will be abolished, schools will descend into chaos. The study reveals that teachers were supportive of using CP in maintaining discipline among students. The study used only questionnaires research instrument during data collection. When using questionnaires, there is a chance that some questions will be ignored or left unanswered.The study did not employ qualitative research instruments during data collection process. Therefore, the current study employed in depth interview guide, documentary review and observation methods to collect qualitative data to triangulate the information obtained from questionnaires.

Invocavity (2014) did a study on the effects of corporal punishment on discipline among students in Arusha Secondary Schools, Tanzania. The study sample included 30 teachers and 3 heads of schools. Data collection by using questionnaires and interview. The study findings indicated that corporal punishment can be administered to students with care in its administration and management. The findings suggest that, teachers should provide non-corporal punishment responses that can be productive to students after completing their studies. Students are advised to follow school rules in order to avoid the punishments. The study sample size was little bit small to generalized the information from the whole population. The small sample size affects the reliability of a survey's results because it leads to a higher variability, which may lead to bias. The current study employed large sample to avoid biases.

\section{Parental Involvement in Their Children Indiscipline Cases in Secondary Schools}

A qualitative study done by Salleh and Rosli (2019) on the parental involvement in discipline management of special education students in schools, Malaysia. The study adopted embedded design. The study sample size was 6 heads of schools, 12 teachers and 18 parents where by in-depth interview guide and observation guide were used for data collection. The study findings indicate that the overall involvement of parents in discipline management of special education students was at a moderate level. Moreover, the study found out that school authorities need to reduce resistance faced by parents so that they can involve themselves in all activities and programs that are carried out by school. Through the cooperation forged between teachers and parents, misconduct and discipline problems of students can be handled collectively by both school and parents. The study seems to be conducted to special education secondary 
schools where by the rate of students to commit indiscipline behaviour was very low due to the nature of schools compared to other normal schools. The researcher could sample pubic secondary schools where by normal students misbehave more and the rate of their parents to visit at schools for making follow ups their children was high. Similarly, the sample size of the parents was too small compared to the design used. This reflects inadequate collection of information from the respondents and the information obtained cannot be generalized from the whole population.

A qualitative study done by Ugwuegbulem (2018) on the exploring parental involvement in public secondary schools in Imo State, Nigeria: The role of socioeconomic status. Semi-structured individual interviews were conducted to parents. The results of this study revealed that irrespective of their social and economic status, parents believed that secondary education was necessary for college education. Influenced by sociocultural norms, the parents perceived parental involvement not as a planned, structured effort directed solely toward the success of children, instead, they viewed participation in their children's education as integral to their overall parental obligations. The findings of the study show the importance of parents' involvement in school activities beside parents were claiming it is not as planned. The use of qualitative research may lead to mislead of conclusion of the study. Data must be recognized by the researchers in qualitative research for it to be collected. That means there is a level of trust present in the data collection process that other forms of research do not require. This studyadopted convergent design which involves the collections of qualitative and qualitative data.

Mbanga, Piliyesi and Anyona (2020), conducted a study on the parental involvement and students' discipline in public day secondary schools in Ilala District in Tanzania. The study used qualitative approach design, phenomenology design was used and in quantitative approach, descriptive design was utilized. The target population for the study was the parents,teachers and students of the public day secondary schools. Findings of the study revealed that parents of secondary schools in Ilala District in Tanzania are involved in solving indiscipline cases among students. In their efforts to deal with the students' indiscipline, the parents offer counselling, attend disciplinary meetings, strive to teach their children good morals and punish their children when involved in indiscipline case. The data obtained through phenomenology design was difficult to analyse and interpret since the researcher involves the parents who are not familiar with involvement in school disciplinary cases. Therefore, this study used convergence design which allows the researcher to collect both qualitative and quantitative data whereby parents was interviewed during data collection.

\section{Methodology}

This study adopted a mixed method approach under which a concurrent embedded design was used. The sample for this study consisted of 4 heads of schools, 16 teachers, 240 students and 8 parents making a total number of 268 respondents.Data necessary to answer the research questions of this study was collected using questionnaires and interview guides. Questionnaires were used to obtain quantitative and qualitative data from teachers while interview guides wereused to gather qualitative information from the heads of schools.

After ensuring that the data collection instruments are improved, the researcher acquired a permission letter from Mwenge Catholic University indicating the purpose of the study. The letter was presented to the district education officer who then introduced the researcher to the heads of schools. Upon arrival to the schools, the researcher conducted sample the teachers and explain them the purpose of the study and ask for their voluntary participation. Then after he distributed the questionnaires and wait for teachers and students to fill before collecting them for analysis. Interviews with heads of schools and parents were conducted separately and each interviewing session last for at most 30 minutes.

The researcher organized the collected data for easy interpretation. Both descriptive and inferential statistics were used to analyze quantitative data whereby the collected data was firstly summarized into frequency, percentages and means. The researcher used computer software (SPSS) version 22 to aid the analysis process. Qualitative data on the other side was thematically whereby the researcher generated themes emerging according to the research questions. Quantitative data was presented in tables while qualitative data was presented in narrations being supported by direct quotations.

\section{Results (Findings and Discussion)}

The study presents the findings about the use of punishment by heads of schools to manage indiscipline cases and heads of schools' involvement of parents in their children indiscipline cases.

\section{The Use of Punishment by Heads of Schools to Manage Indiscipline Cases}

The study sought to find out how punishment was used by head of schools to manage indiscipline cases in public secondary schools. The information to address this question was acquired from Students, teachers, heads of schools and parents. Questionnaires were used to obtain information from students and teachers while interview guide was used to get information from parents and heads of schools. The responses of students and teachers were presented in Tables 1 and 2. 


\begin{tabular}{|c|c|c|c|c|c|c|c|c|c|}
\hline \multirow{2}{*}{ Use of Punishment } & \multicolumn{2}{|c|}{ Never } & \multicolumn{2}{c|}{ Rarely } & \multicolumn{2}{c|}{ Sometimes } & \multicolumn{2}{c|}{ Always } & Mean \\
\cline { 2 - 11 } & $\mathbf{f}$ & $\mathbf{0}$ & $\mathbf{f}$ & $\mathbf{\%}$ & $\mathbf{f}$ & $\mathbf{\%}$ & $\mathbf{f}$ & $\mathbf{\%}$ & 3.68 \\
\hline Sweeping & 0 & 0.0 & 12 & 5.0 & 52 & 21.7 & 176 & 73.3 & 3.32 \\
\hline Grass cutting & 0 & 0.0 & 28 & 11.7 & 108 & 45.0 & 104 & 43.3 & 3.30 \\
\hline Cleaning toilet & 10 & 4.2 & 32 & 13.3 & 73 & 30.4 & 125 & 52.1 & 2.5 \\
\hline Extra class work & 36 & 15.0 & 72 & 30.0 & 89 & 37.1 & 43 & 17.9 & 2.58 \\
\hline Squatting & 76 & 31.7 & 47 & 19.6 & 69 & 28.7 & 48 & 20.0 & 2.37 \\
\hline Isolation & 233 & 97.1 & 7 & 2.9 & 0 & 0.0 & 0 & 0.0 & 1.03 \\
\hline Slapping with the hand & 150 & 62.5 & 75 & 31.3 & 15 & 6.3 & 0 & 0.0 & 1.44 \\
\hline Flogging & 0 & 0.0 & 0 & 0.0 & 24 & 10.0 & 216 & 90.0 & 3.90 \\
\hline Suspension & 33 & 13.8 & 51 & 21.3 & 54 & 22.5 & 102 & 42.5 & 2.94 \\
\hline Kneeling down & 30 & 12.5 & 30 & 12.5 & 72 & 30.0 & 108 & 45.0 & 3.08 \\
\hline Total Mean & & & & & & & & & 2.80 \\
\hline
\end{tabular}

Table 1: Students Responses on the Punishment Used by the Heads of Schools to Manage Indiscipline Cases ( $n=240)$ Source, (2021)

Data from Table 1 represents responses of students on the punishments used by heads of schools to enhance discipline in public secondary schools. The study revealed that flogging is always used by the heads of schools in enhancing discipline to students by $90 \%$ followed by sweeping indicated to be always used by heads of schools by $73.3 \%$ with highest mean of 3.90 and 3.68 respectively. Similarly, the respondents also indicated cleaning toilets, kneeling down and suspension are always used by heads of schools by $52.1 \%, 45.0 \%$ and $42.5 \%$ respectively. Moreover, the respondents have mentioned sometimes heads of schools use grass cutting by $45.0 \%$ and extra class work by $37.1 \%$. The study found that, it was only isolation, slapping with the hand and squatting that were specified to never being used with their percentage of $97.1 \%, 62.5 \%$ and $31.7 \%$ respectively. Generally, data from Table 1 indicates that punishments were being used by the heads of schools in enhancing students discipline in public secondary schools.

The findings mean that majority of heads of schools use several punishments as the strategy towards managing students' discipline. According to Shipera, (2020) flogging of students is used very often and other physical punishments such as hitting with the hand, slapping with the hand, kicking with the leg and pinching with fingers are used illegally in very few cases. Flogging is legal in Tanzania under the National Corporal Punishments Regulations of 1979.However, Government guidelines in 2000, reduced the number of strokes from six to four strokes whereby only heads of schools should punish. Other teachers should punish under the supervision of the head of the school.

This means that teachers used normal punishment like sweeping, grass cutting and cleaning toilets for students who committed indiscipline cases. Maintaining students' discipline now days is said to be the most difficult and unpleasant part of the teaching career due to globalization and the influence of social media. It is not surprising that discipline is categorically the major challenge facing school teachers in Tanzania (Yaghambe, 2013; Semali\&Vumilia, 2016; Kambuga, 2017).Heads of schools were asked to explain the kind of punishments they use for students who break school rules and regulations. One of the head of school said that

I usually used normal punishments like caning students with sticks and provision of extra works after class for normal indiscipline cases such as late comers, students with poor performance and students who wear improper uniform.(28 ${ }^{\text {th }}$ May, 2021)

Another head of school said that

...... beside canning students with stick other forms of punishment experienced in our schools included students being sent out of class, kneeling down, doing manual work, being suspended and expelled from school for a given period of time.(25th May, 2021)

These findings imply that heads of schools used several types of punishment as quickly administered and have a positive impact in managing students' repugnant behaviours. Gwando (2017) observed use of punishment was common in secondary schools aiming at controlling the students' behaviours. Most parents accepted that punishment helped their children to reach their goals academically. For example, one among the parents said that;

... several punishments were used by the head of school during management of our children discipline. Punishment like canning with a stick, suspension, provision of manual works and provision of extra work after class. Since the discipline of a student's start from their homes, I usually teach my children how to behave well in front of adult and their fellow students inside and outside their schools. (24th May, 2021)

This means that parents as primary educators have to teach discipline from home by being positive role models. They also have to provide for and maintain educational resources by raising funds for the school so that the educational needs of the child are met. School discipline may be maintained if parents provide their children with the necessary school resources. Parents have also to provide security to learners and promote respect for the school property. Teachers and parents alike, have to set examples of consistently ethical, just, kind and acceptable behaviour if they want their children to become well behaved and disciplined. Teachers also were asked to indicate types of punishment that heads of school used during management of discipline of students at schools whereby their responses were presented in Table 2. 


\begin{tabular}{|c|c|c|c|c|c|c|c|c|c|}
\hline \multirow{2}{*}{ Punishments } & \multicolumn{2}{|c|}{ Never } & \multicolumn{2}{|c|}{ Rarely } & \multicolumn{2}{c|}{ Sometimes } & \multicolumn{2}{c|}{ Always } & Mean \\
\cline { 2 - 11 } & $\mathbf{f}$ & $\mathbf{\%}$ & $\mathbf{f}$ & $\mathbf{\%}$ & $\mathbf{f}$ & $\mathbf{\%}$ & $\mathbf{f}$ & $\mathbf{\%}$ & \multicolumn{1}{c|}{ M } \\
\hline Sweeping & 2 & 12.5 & 4 & 25.0 & 7 & 43.8 & 3 & 18.8 & 2.69 \\
\hline Grass cutting & 0 & 0.0 & 6 & 37.5 & 8 & 50.0 & 2 & 12.5 & 2.75 \\
\hline Cleaning toilet & 0 & 0.0 & 0 & 0.0 & 4 & 25.0 & 12 & 75.0 & 3.75 \\
\hline Extra class work & 0 & 0.0 & 0 & 0.0 & 3 & 18.8 & 13 & 81.3 & 3.81 \\
\hline Suspension & 0 & 0.0 & 0 & 0.0 & 1 & 6.3 & 15 & 93.8 & 3.94 \\
\hline Isolation & 14 & 87.5 & 2 & 12.5 & 0 & 0.0 & 0 & 0.0 & 1.31 \\
\hline Slapping with the hand & 16 & 100.0 & 0 & 0.0 & 0 & 0.0 & 0 & 0.0 & 1.19 \\
\hline Flogging & 0 & 0.0 & 0 & 0.0 & 2 & 12.5 & 14 & 87.5 & 3.81 \\
\hline Squatting & 3 & 18.8 & 6 & 37.5 & 4 & 25.0 & 3 & 18.8 & 2.44 \\
\hline Kneeling down & 0 & 0.0 & 0 & 0.0 & 5 & 31.3 & 11 & 68.8 & 3.69 \\
\hline Total Mean & & & & & & & & & 2.93 \\
\hline
\end{tabular}

Table 2: Teachers Responses on the Punishment Used by the Heads of Schools to Manage

Indiscipline Cases $(n=16)$

Source, (2021)

The results from Table 2 represent responses from teachers on the punishments used by the heads of schools to enhance discipline to students in public secondary schools. The study findings revealed that suspension indicated to be always used by the heads of schools by $93.8 \%$ with highest mean of 3.94. Similarly, the study findings revealed that flogging, extra class work, cleaning toilets and kneeling down indicated to always being used by the heads of schools by 87.5\%, 81.3\%, 75.0\% and 68.8\% respectively. However, teachers indicated that heads of schools have never slapping students with hand when enhancing discipline to students by mean of 1.19 followed by isolation that teachers have indicated to never being used by heads of schools in enhancing students discipline by mean of 1.31 . Moreover, respondents indicated that grass cutting and sweeping are sometimes used by the heads of schools when enhancing discipline to students by $50 \%$ and $25 \%$ respectively. Generally, the findings of the study revealed that heads of schools used punishments when enhancing discipline to students.

This finding implied that punishments in any public secondary schools are expected to teach students the relationship between their behaviours and the outcome or accountability for their mistakes. Punishments are expected to suppress unwanted response during the time students are under teachers' observation. Some punishments were appropriate and constructive like provision of extra work, standing or kneeling in front of class, exercise drills such as raising arms while carrying weight, suspension and expulsion from schoolwhile others were not desirable like corporal punishment which instilling fear to students. Punishments were perceived as essential to safeguard innocent students against cruel ones. The use of punishment could control students 'behaviour although there was no significant evidence that punishment builds confidence among students.

During interview with heads of schools it was found thatpunishment is the major management strategies used by teachers to deal with the student indiscipline acts. One among the heads of schools said that;

Most of students in my school they are not listening or obey and follow school rules and regulations. So, there is need for using various punishment for students who have discipline problem. However, for the case of punishing students I have already indicated the types of punishment to the teachers that can be used to punish students. Punishment like kneel down in front of the class, standing in front of the class, manual works after class hours and caning students with a stick but only under my supervision. (26 ${ }^{\text {th }}$ May, 2021)

theresult implies that punishment is common strategy used in managing indiscipline cases. Punishment is said to be among management strategy as the education policy of Tanzania argue that the students with the indiscipline acts should be punished accordingly. The interview with the parents, it was argued that the punishments are big enough to their children in the school, they decided to abscond the school, and students have no right to be listened when caught with mistake. One among the parents said that;

Head of school and teachers should find out the reasons before punishing the student, you may find the student is sick that's why he or she comes late. So, when a head of school and teachers punishes students without listening to the students then head of school and teachers are not helping but they are instilling fear to students. Also, the head of school and teachers should cooperate with the students to deal with the problems facing them in school and home. (24th May, 2021)

The finding from parents means that heads of schools and teachers should listing reasons of students before punishing them. Also heads of schools and teachers should establish good relationship students for the purpose of understanding their behaviours and why they misbehave. Teachers have to give the right punishment to the right mistake, the school management ensure every student have the copy of the school rules and regulations, to encourage there is a good cooperation between school management, teachers, parents and students so as to ensure maximum discipline to the students. Punishment can be a form of discouragement to others, that is, punishment given to wrong doers can discourage others from bad behaviours.

Teachers in schools are not only tasked to teach but also at same time are expected to manage students' behaviours to ensure that students engage in the broad activities related to teaching and learning. Evidently, in schools due to overwhelming students' disciplinary cases, teachers spend many hours in correcting the behaviour and less in teaching. Yaghambe (2013) indicates that in Tanzania, common disciplinary problems which teachers address from 
morning as they arrive at schools include truancy, peddling drugs, bullying, smoking, sexual affairs, abusive language, physical fights and theft.

Therefore, punishment as school management tool has however resulted to some violent incidents of students' unrest in some secondary schools. John, (2017) in his study on management of students' discipline in secondary schools in Siha District has revealed that, many violations were experienced in secondary schools and teachers used a wide range of methods in managing students' discipline in schools. This included expulsion, suspension, caning, physical punishments, detention, reprimanding, kneeling, guidance and counselling, fining, rewards, wearing school uniform at all the time, selfcommitment in writing to maintain good conduct, pinching, slapping and smacking.

\section{Heads of Schools Involve Parents in Their Children Indiscipline Cases}

This section sought to find out the how heads of schools involve parents in their children's indiscipline cases in public secondary schools. The information to address this research question was acquired from students, teachers, heads of schools and parents. Questionnaires were used to get information from students and teachers and interview guide was used to obtain information from heads of schools and parents. The results from students and teachers were presented in the Table 3 and 4.

\begin{tabular}{|c|c|c|c|c|c|c|c|c|c|c|c|}
\hline \multirow[t]{2}{*}{ Parental Involvement } & \multicolumn{2}{|c|}{ SD } & \multicolumn{2}{|c|}{ D } & \multicolumn{2}{|c|}{$\mathbf{U}$} & \multicolumn{2}{|c|}{$\mathbf{A}$} & \multicolumn{2}{|c|}{ SA } & \multirow[t]{2}{*}{ Mean } \\
\hline & f & $\%$ & f & $\%$ & $\mathbf{f}$ & $\%$ & $\mathbf{f}$ & $\%$ & f & $\%$ & \\
\hline $\begin{array}{l}\text { Heads of schools use mobile } \\
\text { phones to communicate with } \\
\text { parents whose students commit } \\
\text { indiscipline cases }\end{array}$ & 9 & 3.8 & 12 & 5.0 & 0 & 0.0 & 91 & 37.9 & 128 & 53.3 & 4.32 \\
\hline $\begin{array}{l}\text { Heads of schools use report } \\
\text { forms to communicate with } \\
\text { parents by list the indiscipline } \\
\text { acts of their children }\end{array}$ & 16 & 6.7 & 6 & 2.5 & 62 & 25.8 & 66 & 27.5 & 90 & 37.5 & 3.87 \\
\hline $\begin{array}{l}\text { Heads of schools call parents to } \\
\text { attend school meeting discussing } \\
\text { about student's indiscipline. }\end{array}$ & 10 & 4.2 & 12 & 5.0 & 6 & 2.5 & 66 & 27.5 & 146 & 60.8 & 4.36 \\
\hline $\begin{array}{l}\text { Heads of schools inviting some } \\
\text { parents into school board } \\
\text { meeting to represent others in } \\
\text { discussing rules and regulation } \\
\text { of indiscipline actions }\end{array}$ & 10 & 4.2 & 18 & 7.5 & 30 & 12.5 & 80 & 33.3 & 102 & 42.5 & 4.02 \\
\hline $\begin{array}{l}\text { Heads of schools send memos to } \\
\text { parents whose children commit } \\
\text { indiscipline acts }\end{array}$ & 13 & 5.4 & 15 & 6.3 & 12 & 5.0 & 102 & 42.5 & 98 & 40.8 & 4.07 \\
\hline $\begin{array}{l}\text { Heads of schools use parents' } \\
\text { ideals to control student's } \\
\text { indiscipline }\end{array}$ & 3 & 1.3 & 25 & 10.4 & 12 & 5.0 & 114 & 47.5 & 86 & 35.8 & 4.06 \\
\hline $\begin{array}{l}\text { Heads of schools encourage } \\
\text { parents to provide advice their } \\
\text { children at homes }\end{array}$ & 0 & 0.0 & 3 & 1.3 & 12 & 5.0 & 115 & 47.9 & 110 & 45.8 & 4.38 \\
\hline $\begin{array}{l}\text { Heads of schools privately meet } \\
\text { with parents discussing about } \\
\text { indiscipline issues }\end{array}$ & 6 & 2.5 & 30 & 12.5 & 27 & 11.3 & 97 & 40.4 & 80 & 33.3 & 4.90 \\
\hline $\begin{array}{l}\text { Heads of schools encourage } \\
\text { parents to make follow ups their } \\
\text { children discipline at schools }\end{array}$ & 19 & 7.9 & 18 & 7.5 & 12 & 5.0 & 87 & 36.3 & 104 & 43.3 & 4.00 \\
\hline $\begin{array}{l}\text { Heads of schools invite parents } \\
\text { when punishing students }\end{array}$ & 18 & 7.5 & 14 & 5.8 & 12 & 5.0 & 103 & 42.9 & 93 & 38.8 & 4.00 \\
\hline Total Mean & & & & & & & & & & & 4.19 \\
\hline
\end{tabular}

Source: 2021

Data from Table 3 show the responses of students on how heads of schools involve parents in their children indiscipline cases. The findings revealed that heads of schools involved parents to their children indiscipline cases at school $(M=4.19)$. The findings show that $60.8 \%$ of students strongly agreed to the statement that heads of schools call parents to attend school meeting discussing about student's indiscipline, $27.5 \%$ of students agreed to the statement, $5.0 \%$ of students disagreed to the statement, $4.2 \%$ strongly disagreed to the statement and $2.5 \%$ of students are undecided to the statement. $53.3 \%$ of students strongly agreed to the statement that heads of schools use mobile phones to communicate 
with parents whose students commit indiscipline cases, $37.9 \%$ of students agreed to the statement, $5.0 \%$ of students disagreed to the statement and 3.8\% strongly disagreed to the statement. Moreover, $42.5 \%$ of students strongly agreed to the statement that heads of schools inviting some parents into school board meeting to represent others in discussing rules and regulation of indiscipline actions, $33.3 \%$ of students agreed to the statement, $12.5 \%$ of students are undecided to the statement, $7.5 \%$ of students disagreed to the statement and $4.2 \%$ disagreed to the statement. $45.8 \%$ of students strongly agreed to the statement that heads of schools encourage parents to provide advice their children at homes, $47.9 \%$ of student agreed to the statement,5.0\% of students are undecided to the statement and $1.3 \%$ of students disagreed. $43.3 \%$ of students strongly agreed to the statement that heads of schools encourage parents to make follow ups their children discipline at schools, $36.3 \%$ of students agreed to the statement, $7.9 \%$ of students strongly disagreed to the statement, $7.5 \%$ of students disagreed to the statement and $5.0 \%$ of students are undecided to the statement.

Findings means that heads of schools used various strategies to involve parents into their children discipline. Strategies like call them to come at school, meet with parents privately to discuss about their students' discipline problems, encourage parents to follow ups their children's behaviours, encourage parents to provide advice to their children about good behaviours might improve their children good discipline. Kabiru (2006) parents contributed a lot to their children discipline by among other things being good role models and by being responsible parents. This means that parents who behave good to their children and other people, their children might have good discipline and behave good to their fellow students and other adults. During an interview with the heads of schools about the involvement of the parents to their children discipline problems. Majority of heads of schools agreed to involve parents of those children who are misbehave at school. One of the head of school said that;

I called parents to come at school for the purpose of discussing with them about their children discipline problems. However, most of parents are too busy they do not come at school early or respond when I sent a letter through their children. Therefore, I used several ways to involve parents into their children discipline issues but their responses in most of time are not good.(26 $6^{\text {th }}$ May, 2021)

This finding means that parents are invited to go to school for an interview with the heads of schools to discuss about their children discipline problems. The findings also revealed that parents are too busy that can not find time to come at school when they are invited. The study findings show that some parents are send their representative at schools when they got invited at school for their children discipline problem. Sichon, (2020) parents should be welcome in school and that they should know who to contact to find information regarding their children education and their behaviours. Parents' involvement in school positive student behaviour, that there would be always tracking down on their performances in school, as well as for the parents increase their interaction and discussion with their children and are more responsive and sensitive to their children's social, emotional, and intellectual developmental needs.Parental involvement is essential to student discipline. Working with parents to develop and communicate expectations, creating positive opportunities in school activities and maintaining channels of communication with the parents makes students' discipline to be effective. That parent's engagement plays a vital role in implementing student discipline. Where it motivates students to modify their behaviours they felt being love and supported by their parents. It implies that school heads must persuade parents to be involved in all decisions particularly in policy making in the school. They may be given importance which in return they will become more cooperative and participative. However, teachers were asked the same questions about the ways heads of schools used to involve parents on their children discipline. The researcher asked the same question to the teachers about ways used by the heads of schools to involve parents in their children indiscipline cases and their responses was presented in Table 4.

\begin{tabular}{|c|c|c|c|c|c|c|c|c|c|c|c|}
\hline \multirow[t]{2}{*}{ Parental Involvement } & \multicolumn{2}{|c|}{ SD } & \multicolumn{2}{|c|}{ D } & \multirow{2}{*}{$\begin{array}{l}\mathbf{U} \\
\mathbf{f}\end{array}$} & \multicolumn{3}{|c|}{$\mathbf{A}$} & \multicolumn{2}{|c|}{ SA } & \multirow[t]{2}{*}{ Mean } \\
\hline & f & $\%$ & $\mathbf{f}$ & $\%$ & & $\%$ & f & $\%$ & f & $\%$ & \\
\hline $\begin{array}{l}\text { Heads of schools use mobile phones } \\
\text { to communicate with parents whose } \\
\text { students commit indiscipline cases }\end{array}$ & 0 & 0.0 & 0 & 0.0 & 0 & 0.0 & 6 & 37.5 & 10 & 62.5 & 4.62 \\
\hline $\begin{array}{l}\text { Heads of schools use report forms to } \\
\text { communicate with parents by list } \\
\text { the indiscipline acts of their children }\end{array}$ & 0 & 0.0 & 0 & 0.0 & 0 & 0.0 & 6 & 37.5 & 10 & 62.5 & 3.63 \\
\hline $\begin{array}{l}\text { Heads of schools call parents to } \\
\text { attend school meeting discussing } \\
\text { about student's indiscipline. }\end{array}$ & 0 & 0.0 & 0 & 0.0 & 0 & 0.0 & 10 & 62.5 & 6 & 37.5 & 4.37 \\
\hline $\begin{array}{l}\text { Heads of schools inviting some } \\
\text { parents into school board meeting to } \\
\text { represent others in discussing rules } \\
\text { and regulation of indiscipline actions }\end{array}$ & 0 & 0.0 & 0 & 0.0 & 0 & 0.0 & 6 & 37.5 & 10 & 62.5 & 4.62 \\
\hline $\begin{array}{l}\text { Heads of schools send memos to } \\
\text { parents whose children commit } \\
\text { indiscipline acts }\end{array}$ & 0 & 0.0 & 0 & 0.0 & 0 & 0.0 & 11 & 68.8 & 5 & 31.3 & 4.31 \\
\hline $\begin{array}{l}\text { Heads of schools encourage parents } \\
\text { to make follow ups their children } \\
\text { discipline at homes }\end{array}$ & 0 & 0.0 & 0 & 0.0 & 0 & 0.0 & 10 & 62.5 & 6 & 37.5 & 4.37 \\
\hline
\end{tabular}




\begin{tabular}{|c|c|c|c|c|c|c|c|c|c|c|c|}
\hline \multirow[t]{2}{*}{ Parental Involvement } & \multicolumn{2}{|c|}{ SD } & \multicolumn{2}{|c|}{ D } & \multirow{2}{*}{$\begin{array}{l}\mathbf{U} \\
\mathbf{f}\end{array}$} & \multicolumn{2}{|c|}{$\mathbf{A}$} & \multicolumn{2}{|c|}{ SA } & \multicolumn{2}{|c|}{ Mean } \\
\hline & $\mathbf{f}$ & $\%$ & $\mathbf{f}$ & $\%$ & & $\%$ & $\mathbf{f}$ & $\%$ & $\mathbf{f}$ & $\%$ & \\
\hline $\begin{array}{l}\text { Heads of schools emphasize parents } \\
\text { to provide advice their children at } \\
\text { homes }\end{array}$ & 0 & 0.0 & 0 & 0.0 & 0 & 0.0 & 7 & 43.8 & 9 & 56.3 & 4.56 \\
\hline $\begin{array}{c}\text { Heads of schools privately meet with } \\
\text { parents discussing about } \\
\text { indiscipline issues }\end{array}$ & 0 & 0.0 & 0 & 0.0 & 0 & 0.0 & 10 & 62.5 & 6 & 37.5 & 4.37 \\
\hline $\begin{array}{l}\text { Heads of schools use parents' ideals } \\
\text { to control student's indiscipline }\end{array}$ & 0 & 0.0 & 0 & 0.0 & 0 & 0.0 & 9 & 56.3 & 7 & 43.8 & 4.44 \\
\hline $\begin{array}{c}\text { Heads of schools invite parents } \\
\text { when punishing students at school }\end{array}$ & 0 & 0.0 & 0 & 0.0 & 0 & 0.0 & 5 & 31.3 & 11 & 68.8 & 4.69 \\
\hline Total mean & & & & & & & & & & & 4.39 \\
\hline
\end{tabular}

Source, (2021)

The findings from Table 4.9 show the responses of teachers on how heads of schools involve parents on their children indiscipline cases at school. Teachers revealed that heads of schools involve parents to the indiscipline cases of their children at school $(\mathrm{M}=4.39)$. For example, $68.8 \%$ of the teachers strongly agreed to the statement that heads of schools invite parents when punishing students at school and $31.3 \%$ of teachers agreed to the statement. Followed by $62.5 \%$ of teachers strongly agreed to the statement that heads of schools use mobile phones to communicate with parents whose students commit indiscipline cases while $37.5 \%$ of teachers agreed. Another $62.5 \%$ of teachers strongly agreed to the statement thatheads of schools use report forms to communicate with parents by list the indiscipline acts of their children while $37.5 \%$ of teachers agreed. Similarly, $62.5 \%$ of teachers strongly agreed to the statement thatheads of schools inviting some parents into school board meeting to represent others in discussing rules and regulation of indiscipline actionswhile $37.5 \%$ of teachers agreed to statement.

The findings imply that teachers understand the effort taken heads of schools in involving parents to the indiscipline cases of their children at school. Involvement of parents to the indiscipline cases of their children by heads of schools at school might be due to establish awareness and relationship between parents and teachers towards the development of the children in their behaviours and education. Heads of schools as well as the teachers must strengthen school parent mentoring program and parent education program. Heads of schools should be committed in implementing student discipline school policy which may be constant and firm to what have been agreed in among the objectives of Parents Teachers Association (PTA) as parents have the right be involved to the education of their children by understand and participate all school activities. School heads may be the model of disciplined as well as the teachers.

However, many parents are reluctant to co-operate with the heads of schools in disciplining their children. Many seem to transfer their obligations to the schools, with the result that the schools have to handle all the disciplinary problems. The children will feel more secure and perform and behave better if their parents are involved in school activities. If children with behavioural problems realize that their parents and educators are collaborating to manage difficulties, they experience more consistency and feel more contained. an active relationship between parents and educators has great benefits. Parents can have a greatimpact on their children's behaviour by ensuring that they arrive at school on time, behave correctly, wear relevant clothing, are in possession of required books and equipment and complete tasks on time. For educators to maintain discipline in schools they need support from parents to promote discipline. Parents also have to take responsibility for their children's behaviour.

Parents play a great role on the discipline of the child. Students, who were victims of some indiscipline behaviour, did so because of some personality differences which were a reflection of ineffective socialization, particularly at puberty stage. Violent attacks on others and challenge to authority was most likely a result of lack of inbuilt discipline traits in the learners because the parents did not instil a culture of discipline at the tender age of childhood. Jinot, (2018)observes that parents contribute to children's indiscipline in many ways; by being bad role models and by avoiding parental responsibilities such as teaching their children goodbehaviour. This rebellion was manifest in the groups or gangs the youth formed to showsolidarity in defying the school or societal expectations. The same kinds of groups were formed in schools causing problems in the discipline system of the school

\section{Conclusions and Recommendations}

\subsection{The Use of Punishment by Heads of Schools to Manage Indiscipline Cases}

The study concluded that heads of schools use punishment to manage indiscipline cases to students. punishment as school management tool has however resulted to some violent incidents of students' unrest in some secondary schools. Many violations were experienced in secondary schools and teachers used a wide range of methods in managing students' discipline in schools. This included expulsion, suspension, caning, physical punishments, detention, reprimanding, kneeling, guidance and counselling, fining, rewards, wearing school uniform at all the time, self-commitment in writing to maintain good conduct, pinching, slapping and smacking. 


\subsection{Heads of Schools Involve Parents in Their Children Indiscipline Cases}

The study concluded that heads of schools involve parents in their children indiscipline cases. Parents' involvement in school positive student behaviour, that there would be always tracking down on their performances in school, as well as for the parents increase their interaction and discussion with their children and are more responsive and sensitive to their children's social, emotional, and intellectual developmental needs. Parental involvement is essential to student discipline. Working with parents to develop and communicate expectations, creating positive opportunities in school activities and maintaining channels of communication with the parents makes students' discipline to be effective. That parent's engagement plays a vital role in implementing student discipline.

The study recommended that the Ministry of Education should provide policy guidelines on the use of guidance and counselling for the management of discipline in secondary schools. Increased efforts should also be made by the Ministry of Education, Department of Directorate of Quality Assurance and Standards to regularly supervise and monitor the schools which were not adhering to the ban on corporal punishment and were violating the child rights. The study recommends that heads of schools and other stakeholders continue capacitating teachers on the appropriate use of harmless strategies of executing corporal punishment approved by the government.

\section{References}

i. $\quad$ Andrews, S. (2018). Management of Students' Discipline in Private Secondary Schools in

ii. Bussienei, A. S. (2012). Alternative Methods of Corporal Punishment and their Efficacy. Journal of Emerging Trends in Educational Research and Policy Studies, 3(2), 155-161.

iii. Bwire, J. B. (2017). The role of public secondary school heads in managing students' discipline in musoma municipality [Thesis, University of Dar es Salaam,].

http://41.86.178.5:8080/xmlui/handle/123456789/10027

iv. Cresswell. J. W. (2014). Qualitative Inquiry of Research Design: choosing Among Five Approaches (4th Ed.) Thousand Oaks, CA: SAGE.

v. Da Silva, A. P. M., Negreiros, F., \& Albano, R. (2016). Indiscipline at Public School: Teachers' Conceptions on Causes and Intervention. International Journal of Research in Education and Science, 3(1), 1-10. https://doi.org/10.21890/ijres.267354

vi. Duda, H. J., \&Susilo, H. (2018). Science Process Skill Development: Potential of Practicum Through Problems Based Learning and Authentic Assessment. Anatolian Journal of Education, 3(1), 51-60.

vii. Gershoff, E. T. (2017). School corporal punishment in global perspective: Prevalence, outcomes, and efforts at intervention. Psychology, Health \& Medicine, 22(sup1), 224-239.

https://doi.org/10.1080/13548506.2016.1271955

viii. Invocavity, J. (2014). The Effects of Corporal Punishment on Discipline Among Students in Arusha Secondary Schools [Published]. Open University of Tanzania.

ix. Ishengoma, P. (2014). A Study on the Use of Corporal Punishment in Maintaining Discipline in Dodoma Municipality Secondary Schools [Published]. University of Dodoma.

x. Jinot, B. L. (2018). Barriers to the Effective Implementation of Behavioural Strategies by Principals of State Secondary Schools in Mauritius. Mediterranean Journal of Social Sciences, 9(4), 9-18. https://doi.org/10.2478/mjss-2018-0110

xi. Jinot, B. L. (2018). Barriers to the Effective Implementation of Behavioural Strategies by Principals of State Secondary Schools in Mauritius. Mediterranean Journal of Social Sciences, 9(4), 9-18. https://doi.org/10.2478/mjss-2018-0110

xii. John, K. (2013). Challenges Faced by Head Teachers in the Management of Students' Indiscipline in Public Schools in Norway, Greece. [MA thesis]. University of Oslo.

xiii. John, K. A. (2017). Factors Leading to Indiscipline in Secondary Schools in Siha District Council, Tanzania [Unpublished]. Open University.

xiv. Kambuga, Y. (2017). The Challenge of Managing Pupils' Discipline in Tanzanian Schools. Journal of Administrative Management and Training. 13 (2): 25-33.

xv. Kambuga, Y. (2017). The Challenge of Managing Pupils' Discipline in Tanzanian Schools. Journal of Administrative Management and Training. 13 (2): 25-33

xvi. Kambuga, Y., Manyengo, P., \&Mbalamula, Y. (2018a). Corporal Punishment as a Strategic Reprimand used by Teachers to curb Students' Misbehaviours in Secondary Schools: Tanzanian Case. International Journal of Education and Research, 6(4), 182-194.

xvii. Kambuga, Y., Manyengo, P., \&Mbalamula, Y. (2018b). Corporal Punishment as a Strategic Reprimand used by Teachers to curb Students' Misbehaviours in Secondary Schools: Tanzanian Case. International Journal of Education and Research, 6(4), 183-194.

xviii. Koda, G. M., \&Kayombo, J. (2019). Influence of Mobile Phone Use on Secondary Schools Students' Discipline, in Moshi Municipality, Kilimanjaro, Tanzania. International Journal of Innovative Research \& Development, 8(1), 81-92.

xix. Machumbu, J. H., \&Killungwe, Z. K. (2013). Stakeholders' Perceptions on Discipline Management as a Means to improve Students' Performance.Mzumbe University.

xx. Maingi, D., Maithya, R., \&Migosi, J. (2017). Influence of school rules' formulation on students' discipline in public secondary schools in Makueni County, Kenya. International Journal of Humanities and Social Science Invention, 6(1), 1-6. 
xxi. Mbanga, B. G., Piliyesi, E., \&Anyona, J. (2020). Parental Involvement and Students' Discipline in Public day Secondary Schools at Ilala District in Tanzania. Journal of Popular Education in Africa, 4(7), 139-156.

xxii. Musa, M., \& Martha, A. A. (2020). School Management Mechanisms and Control of Discipline among Pupils in Primary Schools: An Analysis of Discipline in Upper Primary Level. Anatolian Journal of Education, 5(1), 1-16.

xxiii. Mwaura, W. W., \&Thinguri, R. (2015b). An Empirical Review Of Strategies Used By School Managers To Enforce Discipline Among Secondary Schools' Students In Public Secondary Schools In Yatta Sub-County, Eastern Region- Kenya. Researchjournali's Journal of Education, 3(1), 12.

xxiv. Nampoto, H. B. (2018). Aspects of Corporal Punishment on Maintaining Discipline in Tanzania Secondary Schools in MtwaraMikindani Municipality [Published]. Open University of Tanzania.

xxv. Ngalya, E. J. (2017). Management of Students' Indiscipline Cases in Public Secondary Schools in Temeke Municipality [Unpublished]. Open University of Tanzania.

xxvi. Salleh, N. M., \&Rosli, F. N. (2019). Parental Involvement in Discipline Management of Special Education Students in Schools. International Journal of Academic Research in Progressive Education and Development, 8(4), Pages 912-920. https://doi.org/10.6007/IJARPED/v8-i4/6781

xxvii. Salleh, N. M., \&Rosli, F. N. (2019). Parental Involvement in Discipline Management of Special Education Students in Schools. International Journal of Academic Research in Progressive Education and Development, 8(4), Pages 912-920. https://doi.org/10.6007/IJARPED/v8-i4/6781

xxviii. Semali, L. M., \&Vumilia, P. L. (2016). Challenges Facing Teachers' Attempts to Enhance Learners' Discipline in Tanzania's Secondary Schools. World Journal of Education, 6(1), 50. https://doi.org/10.5430/wje.v6n1p50

xxix. Semali, L., \&Vumilia, P. (2016). Challenges Facing Teachers' Attempts to Enhance Learners' Discipline in Tanzania's Secondary Schools. World Journal of Education, 6. https://doi.org/10.5430/wje.v6n1p50

xxx. Sichon, D. J. S. (2020). Implementing An Effective Student Discipline: School Heads' Perspective. International Journal of Scientific \& Technology Research, 9(03), 24.

xxxi. Ugwuegbulem, L. N. (2018). Exploring Parental Involvement in Public Secondary Schools in Imo State, Nigeria: The Role of Socioeconomic Status [Thesis]. Seton Hall Univeristy.

xxxii. United Republic of Tanzania (URT). (2020). United Republic of Tanzania / Global Initiative to End All Corporal Punishment of Children. https://endcorporalpunishment.org/reports-on-every-state-and-territory/unitedrepublic-of-tanzania/

xxxiii. URT. (2015). United Republic of Tanzania | Global Initiative to End All Corporal Punishment of Children. End Corporal Punishment.

https://endcorporalpunishment.org/reports-on-every-state-and-territory/united-republic-of-tanzania/

xxxiv. Yaghambe, S. R. (2013). Disciplinary Networks in Secondary Schools: Policy Dimensions and Children's Rights in Tanzania. Journal of Studies in Education. 3 (4):42-56.

xxxv. Yaghambe, S. R. (2019). Disciplinary Networks in Secondary Schools: Policy Dimensions and Children's Rights in Tanzania. Journal of Studies in Education. 3 (4):42-56. 